\title{
Manihot (Euphorbiaceae s.s.) no Parque Estadual da Serra Dourada, Goiás, Brasil
}

\author{
Manihot in Serra Dourada State Park, Goiás, Brazil
}

\author{
José Eustáquio do Carmo Júnior ${ }^{1,3}$, Rodolfo Carneiro Sodré ${ }^{1}$, Marcos José da Silva ${ }^{1}$ \\ \& Margareth Ferreira de Sales ${ }^{2}$
}

\begin{abstract}
Resumo
O Parque Estadual da Serra Dourada compreende um mosaico vegetacional e é uma das áreas serranas mais conservadas do estado de Goiás. Com intuito de contribuir com a flora deste parque e com o conhecimento da diversidade das Euphorbiaceae no Cerrado s.l. apresenta-se aqui o tratamento taxonômico do gênero Manihot. Foram encontrados 11 táxons, entre eles nove espécies e duas subespécies: M. anomala Pohl, M. anomala subsp. pubescens (Pohl) D.J. Rogers \& Appan, M. gracilis Pohl, M. irwinii D.J. Rogers \& Appan, M. mossamedensis Taub., M. oligantha Pax, M. paviifolia Pohl, M. pentaphylla Pohl, M. pentaphylla subsp. tenuifolia (Pohl) D.J. Rogers \& Appan, M. sparsifolia Pohl e M. xavantinensis D.J. Rogers \& Appan. São apresentados aqui descrições, chave de identificação, ilustrações, distribuição geográfica, além de comentários acerca da morfologia e das preferências ecológicas das espécies analisadas.
\end{abstract}

Palavras-chave: Cassava, diversidade, endemismo, flora do Cerrado, sistemática.

\begin{abstract}
The Serra Dourada State Park comprises a mosaic of vegetation and it is one the most conserved and diverse mountainous areas of Goiás state. To contribute to the flora of this park and with knowledge of Euphorbiaceae diversity in the Cerrado s.l. vegetation a taxonomic treatment of the genus Manihot is presented here. Eleven taxa arranged in nine species were recognized: M. anomala Pohl, M. anomala subsp. pubescens (Pohl) D.J. Rogers \& Appan, M. gracilis Pohl, M. irwinii D.J. Rogers \& Appan, $M$. mossamedensis Taub., M. oligantha Pax, M. paviifolia Pohl, M. pentaphylla Pohl, M. pentaphylla subsp. tenuifolia (Pohl) D.J. Rogers \& Appan, M. sparsifolia Pohl and M. xavantinensis D.J. Rogers \& Appan. Descriptions, illustrations, comments on morphological similarities, geographic distribution and ecological preferences of species, and a key to identify are provided.
\end{abstract}

Key words: Cassava, diversity, endemism, flora of the Cerrado, systematics.

\section{Introdução}

Manihot Miller compreende cerca de 100 espécies americanas, a maioria (ca. 80) brasileira. O gênero se destaca pela complexidade taxonômica, decorrente principalmente da plasticidade morfológica foliar, homogeneidade floral e frequente hibridização natural (Rogers \& Appan 1973; Duputié et al. 2011). Inclui plantas subarbustivas a arbustivas, raro trepadeiras ou arbóreas, lactescentes com folhas geralmente lobadas, flores variando de gamo a dialisépalas, com disco nectarífero de ambas as flores comumente lobado, androceu com 10 estames em duas classes de altura, além de frutos capsulares e sementes carunculadas (Rogers \& Appan 1973; Webster 1994).

Espécies de Manihot são popularmente conhecidas como mandioca, mandioca-braba, mandioca-brava, manioca, aipim ou macaxeira e são amplamente utilizados na alimentação, particularmente $M$. esculenta Crantz, por apresentar raízes ricas em carboidratos (Olsen \& Schall 1999).

Manihot foi descrito por Miller (1754) e teve sua taxonomia revisada por Rogers \& Appan (1973), os quais reconheceram para o gênero 19

\footnotetext{
${ }^{1}$ Universidade Federal de Goiás, Instituto de Ciências Biológicas, Depto. Biologia Geral, Campus Samambaia II, C.P. 131, 74001-970, Goiânia, GO, Brasil.

${ }^{2}$ Universidade Federal Rural de Pernambuco, Depto. Biologia, 52171-900, Recife, PE, Brasil.

${ }^{3}$ Autor para correspondência: jecj-taxonomy@hotmail.com
} 
seções. Entretanto, a maioria destas seções não se mostrou monofilética nos estudos filogenéticos de Chacón et al. (2008) e Duputié et al. (2011), os quais confirmaram o monofiletismo do gênero.

Após a revisão feita por Rogers \& Appan (1973), alguns táxons foram descritos para este gênero (Allem 1989b, 1999, 2001; Martins et al. 2011; Nassar 1985; Nassar et al. 2011). Mesmo assim, o conhecimento sobre Manihot na flora brasileira ainda é escasso e encontra-se desatualizado (Secco et al. 2012), embora o mesmo tenha sido monografado para algumas floras regionais, como a de Santa Catarina, (Smith et al. 1988), do Distrito Federal (Rodrigues 2007) e do Rio Grande do Sul (Allem 1997) e, também tenha sido citado em estudos florísticotaxonômicos pontuais (Cordeiro 1992; Santos-Filho 2000; Sátiro \& Roque 2008), entre outros.

Para o estado de Goiás, inexistem estudos taxonômicos sobre Manihot, embora o gênero seja um dos mais diversos, conforme levantamentos de herbários. Sendo assim, este estudo apresenta o tratamento taxonômico deste gênero no Parque Estadual da Serra Dourada, que é parte do referido estado.

\section{Materiais e Métodos}

O Parque Estadual da Serra Dourada (PESD) compreende a Serra Dourada, distando $131 \mathrm{~km}$ de Goiânia e engloba os municípios de Mossâmedes e Goiás (Rizzo 1970). Possui uma área de 30.000 hectares, localizada entre as coordenadas geográficas $16^{\circ} 06^{\prime} 02^{\prime \prime}-16^{\circ} 03^{\prime} 52^{\prime \prime} \mathrm{S}$ e $50^{\circ} 10^{\prime} 59^{\prime \prime}$ $-50^{\circ} 10^{\prime} 12^{\prime \prime} \mathrm{W}$, recoberta por Cerrado s.s., Cerrado rupestre, Floresta semidecídua, Floresta de galeria, Campo limpo e Campo sujo. Seu relevo varia de plano a fortemente ondulado, com afloramentos de arenito, incluindo "paredões" e possui altitude que varia de 726 até 1080 metros. Seu clima é o Aw com chuvas desde outubro a abril (Köppen 1948) e temperatura média anual de $23,6^{\circ} \mathrm{C}$ (Cochrane et al. 1985). De acordo com Rizzo (1970), sua flora é diversificada com a presença de táxons endêmicos, tais como Chamaecrista desvauxii var. peronadenia
H.S. Irwin \& Barneby, Chamaecrista orbiculata var. trichotyrsus (Harms) H.S. Irwin \& Barneby, Hyptis angustifolia Pohl ex Benth., Lomatozona artemisiifolia Baker ou pouco conhecidos, como Croton gracilescens Müll. Arg. e Myrcia virgata Cambess.

Foram realizadas excursões mensais de outubro de 2010 a abril de 2012 para coleta de material botânico, conforme metodologia de Mori et al. (1989). A identificação dos táxons foi baseada, principalmente, no estudo de Rogers \&Appan (1973), e na comparação com as coleções dos herbários UB, CEN e UFG (acrônimos conforme Thiers et al. 2012). A terminologia adotada nas descrições das espécies foram baseadas em Rogers \& Appan (1973) e Radford et al. (1974). As ilustrações foram feitas com o auxílio de um estereomicroscópio Zeiss, com câmara clara acoplada, e o material botânico coletado encontra-se depositado no Herbário UFG.

\section{Resultados e Discussão}

Manihot Mill., Gard. Dict. Arb., ed. 4. 851. 1754. Subarbustos ou arbustos, raro trepadeiras ou árvores, monóicos, lactescentes. Caule e ramos glabros a indumentados, verde-glaucos a vináceos. Estípulas caducas ou persistentes, inteiras ou laciniadas. Folhas simples, pecioladas, alternoespiraladas, membranáceas a coriáceas, inteiras ou lobadas; nervuras róseo-vináceas a verdeamareladas, impressas ou proeminentes; discolores, face adaxial verde lustrosa, face abaxial verdeglauca e usualmente cerosa. Panículas ou racemos, típicos ou espiciformes, uni- ou bissexuais, solitários ou em conjuntos de até 3 na dicotomia dos ramos. Brácteas semelhantes às estípulas. Flores unissexuais, subsésseis a pediceladas, 5-meras, actinomorfas, gamo ou dialissépalas, verde-claras a esbranquiçadas, maculadas ou não; disco usualmente lobado, estames 10, livres em duas classes de altura, glabros a indumentados, anteras dorsifixas; ovário 3-carpelar, 3-locular, uniovulado, estiletes 3, ramos estigmáticos franjados. Cápsulas usualmente globosas, glabras a indumentadas, costadas a lisas. Sementes geralmente oblongoides, carunculadas.

\section{Chave para as espécies de Manihot do Parque Estadual da Serra Dourada}

1. Lobos foliares lineares.

2. Plantas $15-25 \mathrm{~cm}$ alt.; estípulas persistentes; racemo unissexuado 5. M. oligantha

2'. Plantas 0,6-1,2 m alt; estípulas caducas; racemo bissexuado.

3. Folhas 5-lobadas, lobos não sobrepostos basalmente; filete glabro 7. M. pentaphylla

3'. Folhas 3(5)-lobadas, lobos sobrepostos basalmente; filete pubescente 2. M. gracilis

1'. Lobos foliares oblongos, obovais, elípticos, lanceolados ou combinações destas formas. 
4. Folhas coriáceas com nervuras principais róseas a vináceas, espessas; frutos costados.

5. Subarbustos $0,15-0,6 \mathrm{~m}$ alt; ; lobos foliares com ápice agudo; flores pistiladas gamossépalas ..... . 8. M. sparsifolia

5'. Arbustos 1-4,5 m alt.; lobos foliares com ápice cuspidado; flores pistiladas dialissépalas.

6. Ramos tomentosos; folhas (3)5-7-lobadas, nervuras secundárias arqueadas; cálice de ambas as flores verde-amarelados 4. M. mossamedensis

6'. Ramos glabros; folhas 3-lobadas, nervuras secundárias subparalelas; cálice de ambas as flores vináceos

3. M. irwinii

4'. Folhas cartáceas a membranáceas com nervuras principais verdes a amareladas, delgadas; frutos não costados.

7. Ramos, face abaxial da lâmina foliar e frutos curtamente tomentosos; folhas 3-5-lobadas ou raro inteiras, lobos frequentemente pandurados 1. M. anomala

7'. Ramos, face abaxial da lâmina foliar e frutos glabros; folhas usualmente 3-lobadas, nunca inteiras, lobos nunca pandurados.

8. Lobos foliares com ápice caudado; brácteas estaminadas $11-16 \times 2-5 \mathrm{~mm}$; pedicelo da flor pistilada com 4-6 mm compr. 6. M. paviifolia

8. Lobos foliares com ápice agudo a curto-acuminado; brácteas estaminadas 3-7 × 1-1,5 mm; pedicelo da flor pistilada com $10-12 \mathrm{~mm}$ compr. 9. M. xavantinensis

1. Manihot anomala Pohl, Pl. Bras. Ic. et. Descr. 1: 27. t. 21. 1827.

Arbusto 0,8-2 m alt., ereto; látex amarelado; ramos curtamente tomentosos; estípulas caducas. Pecíolo 5-12 cm compr.; lâmina foliar 3-5-lobada, raro inteira, membranácea, face abaxial curtamente tomentosa, lobos 9,5-15 × 1-6 cm, elípticos, elíptico-obovais ou oblongos, inteiros a pandurados, não sobrepostos basalmente, ápice acuminado, nervuras delgadas, esbranquiçadas, as secundárias arqueadas. Racemo-espiciforme 5-12 cm compr., bissexuado, subereto, laxo. Flores estaminadas 1-2,1 cm compr.; botões 4-7 mm compr., globoides; pedicelo $0,5-1 \mathrm{~cm}$ compr.; brácteas 2-11 × 3-10 mm, ovais a lanceoladas, inteiras, agudas, pubescentes, verde-esbranquiçadas, persistentes ou caducas; cálice gamossépalo 5-11 $\times$ 4-8,5 mm, campanulado, branco-esverdeado com fauce vinácea, lobos 3-7 × 2-5 mm, triangulares a ovais, agudos; filetes glabros. Flores pistiladas 0,8-2,2 cm compr.; botões 5-10 mm compr., ovoides a oblongoides; pedicelo $0,4-1 \mathrm{~cm}$ compr.; brácteas $2-9 \times 0,6-1,5 \mathrm{~mm}$, lanceoladas, inteiras a laciniadas, agudas, pubescentes, verdeesbranquiçadas, persistentes ou caducas; cálice dialissépalo, sépalas 4-12 × 2,2-4 mm, lanceoladas, agudas, verde-amareladas com ou sem estrias vináceas; ovário 2-5 × 3-4 mm, oblongoide, disco amarelo-avermelhado a vináceo. Cápsulas 7-10 $\times$ 5-6 mm, elipsoides, não costadas, curtamente tomentosas, verde-escuras. Sementes não vistas.

Foram encontradas duas subespécies para Manihot anomala no PESD, reconhecidas pela chave abaixo:

1. Brácteas estaminadas $8-11 \times 3-5 \mathrm{~mm}$ compr., persistentes, encobrindo o botão

1b. M. anomala subsp. pubescens

1'. Brácteas estaminadas 2-4 × 0,5-1 mm compr., caducas, não encobrindo o botão

1a. M. anomala subsp. anomala

1a. Manihot anomala Pohl subsp. anomala

Fig. 1

Manihot anomala subsp. anomala ocorre nas regiões Centro-Oeste (Distrito Federal, Goiás, Mato Grosso) e Sudeste (Minas Gerais e São Paulo) associada a floresta estacional semidecidual sobre solo argiloso ou argilo-pedregoso. No PESD foi encontrada na floresta de galeria do Córrego do Piçarrão e na borda da floresta estacional acima deste.
Assemelha-se morfologicamente a $M$. anomala subsp. pubescens (Pohl) D.J. Rogers \& Appan pelos ramos jovens, face abaxial das folhas e cápsulas curtamente tomentosas, racemoespiciformes, folhas 3-5-lobadas, raro inteira, geralmente panduradas e flores estaminadas com fauce vinácea. Em M. anomala subsp. anomala as brácteas estaminadas são caducas, menores que a metade do botão e as pistiladas 


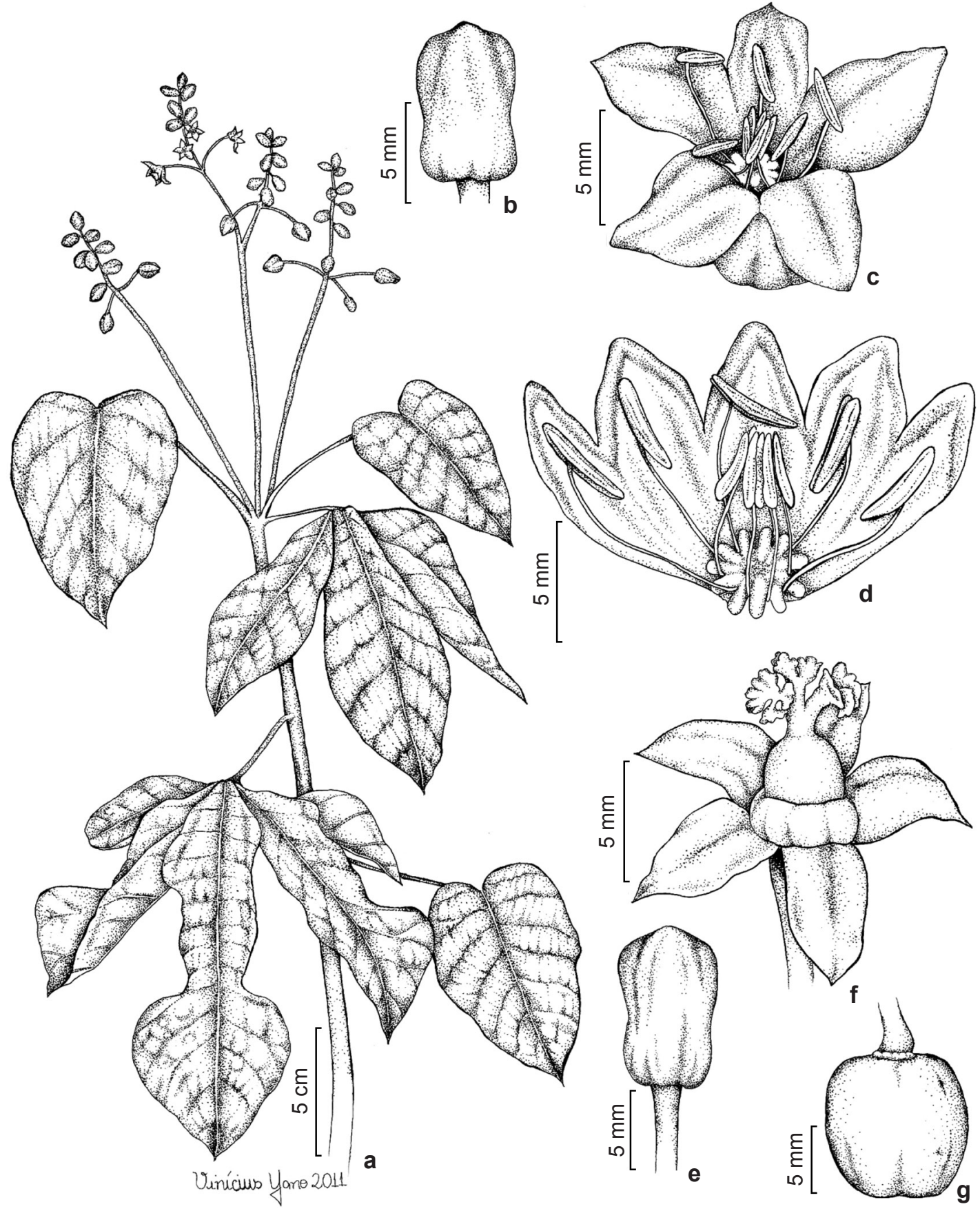

Figura 1 - Manihot anomala subsp. anomala. a. ramo florido; b. botão estaminado; c. flor estaminada; d. flor estaminada aberta; e. botão pistilado; f. flor pistilada; g. fruto (M.J. Silva 3152).

Figure 1 - Manihot anomala subsp. anomala. a. flowering branch; b. staminate bud; c. staminate flower; d. staminate flower opened out; e. pistillate bud; f. pistillate flower; g. fruit. (M.J. Silva 3152).

medem 1,2-1,5 mm larg., enquanto M. anomala subsp. pubescens possui brácteas estaminadas persistentes encobrindo o botão e pistiladas com $0,6-0,8 \mathrm{~mm}$ larg. Associado a isto, em M. anomala subsp. pubescens os ramos são mais indumentados e folhas são menos frequentemente panduradas, quando comparada a espécie típica. Floresce e frutifica entre outubro a janeiro. 
Material examinado selecionado: borda da mata acima do Córrego Piçarrão, 28.X.1997, fl., V.L. Gomes-Klein et al. 3384 (UFG); mata de galeria do Córrego Piçarrão, 30.X.2010, fl. e fr., M.J. Silva 3152, 3153 (UFG); floresta semidecidual acima do Córrego Piçarrão, 17.XI.2010, fl., M.J. Silva 3221, 3223, 3224 (UFG); 30.XI.2010, fl., J.E.C. Júnior 103, 104, 106, 107 (UFG).

Material adicional: BRASIL. GOIÁS: Alto Paraíso de Goiás, Chapada dos Veadeiros, Vale da lua, 20.I.2012, fl. e fr., R.C. Sodré 10 (UFG).

1b. Manihot anomala subsp. pubescens (Pohl) D.J. Rogers \& Appan, Fl. Neotrop. Monogr. 13: 167. 1973.

Fig. 2

Material examinado selecionado: morro da antena de rádio, 1558'00"S, 5008'00”W, $496 \mathrm{~m}$, 1.II.1999, fl. e fr., I.R.S. Costa 1099 (CEN); estrada que leva à sede na parte superior da floresta estacional, 30.XI.2010, fl., J.E.C. Júnior 105, 108 (UFG); 17.XII.2010, fl., M.J. Silva 3220 (UFG).

Material adicional: BRASIL. GOIÁS: Goianápolis, Parque Estadual Altamiro de Souza Pacheco, 16033'6,6"S, 4907' 57,8” W, 31.III.2005, fl. e fr., R.C. Mendoça 5918 (UFG); Iporá, cerca de $16,9 \mathrm{~km}$ a NE rodovia GO060 rumo a o Israelândia, $16^{\circ} 20^{\prime} \mathrm{S}, 50^{\circ} 59^{\prime} \mathrm{W}, 440$ m, 11.XI.1996, fl. e fr., A.C. Allem et al. 4606 (CEN).

Táxon com ocorrência no Pará, Minas Gerais, Goiás e Distrito Federal (Rogers \& Appan 1973 ) associado à floresta estacional semidecidual ou mata de galeria. $\mathrm{Na}$ área de estudo, cresce simpatricamente à $M$. anomala subsp. anomala na estrada que leva a sede do PESD e no morro da antena de rádio no município de Goiás. Coletada com flores entre novembro e maio e com frutos em maio e novembro.

2. Manihot gracilis Pohl, Pl. Bras. Ic. et Descr. 1: 23, t. 16. 1827.

Fig. 3

Subarbusto 0,6-1,1 m alt., ereto; látex amarelado; ramos glabros; estípulas caducas. Pecíolo 2,5-4 cm compr.; lâmina foliar 3(5)-lobada, membranácea, face abaxial glabra, lobos 6,5-15,2 $\times 0,5-0,7 \mathrm{~cm}$, lineares, inteiros, sobrepostos basalmente, ápice acuminado, nervuras delgadas, amarelas, as secundárias subparalelas. Racemo 2-6 cm compr., bissexuado, subereto, laxo. Flores estaminadas 1,1-2,8 cm compr.; botões 3-5 mm compr., cônicos; pedicelo 0,8-1,2 cm compr.; brácteas 8-12 × 2-3 mm, lanceoladas, inteiras a ligeiramente denteadas, agudas, glabras, verde-amareladas, persistentes; cálice gamossépalo 1,3-1,6 × 0,3-0,5 $\mathrm{cm}$, campanulado, verde-amarelado com máculas vináceas, lobos 8-12 × 2-3 mm, triangulares a ovais, agudos; filetes pubescentes. Flores pistiladas 1,1-1,8 cm compr.; botões 4-6 mm compr., elipsoides; pedicelo
0,3-0,6 mm compr.; brácteas $2-5 \times 0,6-0,8 \mathrm{~mm}$, lanceoladas a lineares, inteiras, agudas, glabras, verdeamareladas, persistentes; cálice dialissépalo, sépalas 0,8-1,2 × 0,2-0,3 mm, lanceoladas, agudas, amareloesverdeadas a esbranquiçadas com máculas vináceas internamente; ovário 3-4× 1,4-1,8 mm, oblongoide; disco amarelo. Cápsulas 8-10 × 7-8 mm, globoides, não costadas, glabras, verdes. Sementes 7-8 $\times$ 4-5 $\mathrm{mm}$, oblongoides, marrom-claras com máculas negras. Material examinado selecionado: entre os córregos do Piçarrão e Cafundó, $2^{\circ}$ transecto, 18.X.1994, fl., J.A. Rizzo 11918 (UFG); distrito de Mirandopólis, Fazenda do Rildo, 27.XI.2010, fl., M.J. Silva 3195 (UFG); acima do Córrego Piçarrão, 16 5,21'02'S, 50 11'51'W, 788 m, 28.I.2011, fl. M.J. Silva 3336 (UFG); 29.I.2011, fl. e fr., M.J. Silva 3381 (UFG).

Manihot gracilis é referida para o Paraguai, Distrito Federal, Goiás, Minas Gerais e São Paulo, conforme Rogers e Appan (1973). No PESD cresce em Cerrado s.s. próximo às cachoeiras ou em interflúvios em solos argilo-pedregosos.

Entre os táxons estudados de folhas com lobos lineares é o único com folhas predominantemente 3-lobadas, sendo os lobos laterais horizontais a eriçados em relação ao eixo da folha, o que o torna fácil de ser reconhecido. Floresce e frutifica de outubro a março.

Embora considerada por Allem (1989a) como uma subespécie de $M$. tripartita (Spreng.) Müll. Arg. preferimos manter M. gracilis como uma espécie distinta, uma vez que a mesma possui folhas com face abaxial glabra, lobos linear e brácteas lanceoladas a lineares com margem inteira a ligeiramente denteadas ( $v s$. folhas com face abaxial curtamente tomentosas, lobos elípticos a largamente elípticos e brácteas elípticas com margem laciniada em $M$. tripartita), além de ser uma planta glabra (vs. usualmente tomentosa).

3. Manihot irwinii D.J. Rogers \& Appan, Fl. Neotrop. Monogr. 13: 137. $1973 . \quad$ Fig. 4

Arbusto 1-1,5 m alt., ereto; látex amarelado; ramos glabros; estípulas caducas. Pecíolo 4-9,5 cm compr.; lâmina foliar 3-lobada, raro inteira, coriácea, face abaxial indumentada, lobos 8,4-12 $\times$ 1,6-8,5 cm, oblongo-obovais, elíptico-obovais ou obovais, inteiros, sobrepostos basalmente, ápices cuspidados, nervuras principais espessas, róseas a vináceas, as secundárias delgadas, subparalelas, amareladas. Racemo 6-15 cm compr., bissexuado, subereto, laxo. Flores estaminadas 0,8-1,2 cm compr; botões 3-5 mm compr., ovoides; pedicelo 0,1-0,3 cm compr.; 

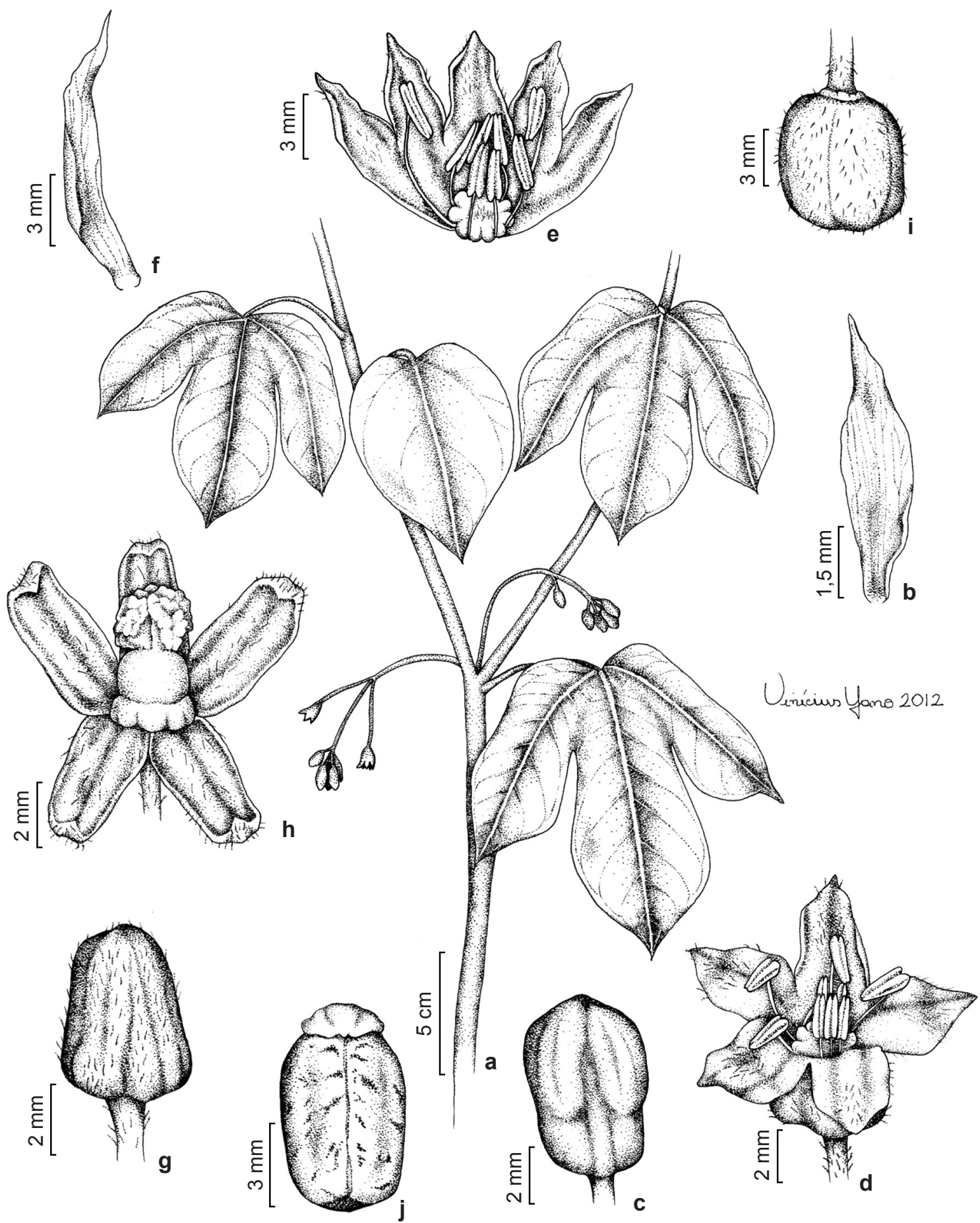

Figura 2 - Manihot anomala subsp. pubescens. a. ramo florido; b. bráctea estaminada; c. botão estaminado; d. flor estaminada. e. flor estaminada aberta; f. bráctea pistilada; g. botão pistilado; h. flor pistilada; i. fruto; j. semente (I.R.S. Costa 1099).

Figure 2 - Manihot anomala subsp. pubescens. a. flowering branch; b. staminate bract; c. staminate bud; d. staminate flower; e. staminate flower opened out; f. pistillate bract; g. pistillate bud; h. pistillate flower; i. fruit; j. seed (I.R.S. Costa 1099). 


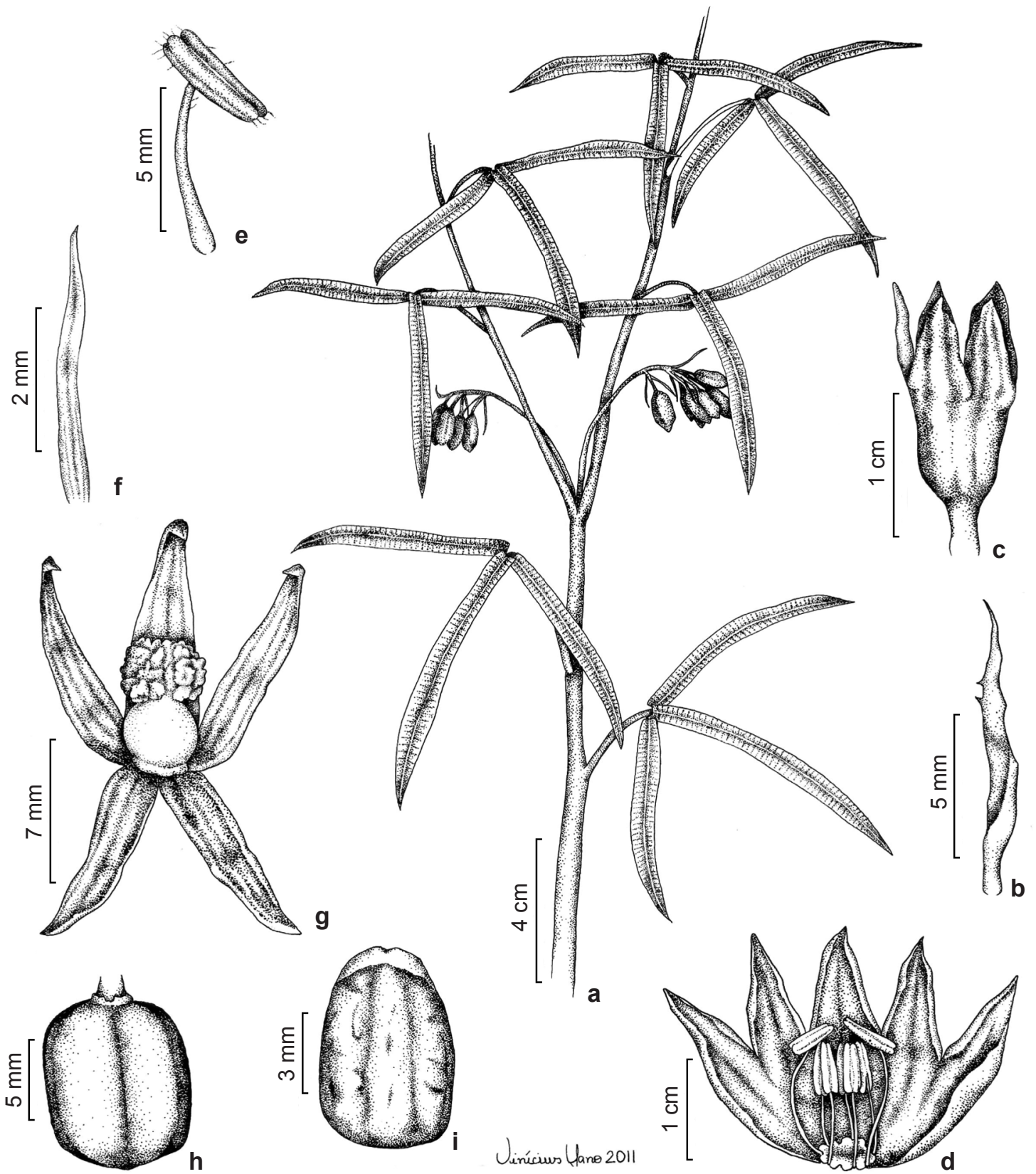

Figura 3 - Manihot gracilis. a. ramo florido; b. bráctea estaminada; c. flor estaminada.; d. flor estaminada aberta; e. estame; f. bráctea pistilada; g. flor pistilada; h. fruto; i. semente (M.J. Silva 3381).

Figure 3 - Manihot gracilis. a. flowering branch; b. staminate bract; c. staminate flower; d. staminate flower opened out; e. stamen f. pistillate bract; g. pistillate flower; h. fruit; i. seed (M.J. Silva 3381).

brácteas $10-12 \times 2-3,5 \mathrm{~mm}$, estreitamente lanceoladas, inteiras, acuminadas, vináceas a roxeadas, persistentes; cálice gamossépalo 7-8,5 $\times$ 9-10 mm, largamente campanulado, vináceo com margem amarelada, lobos 4-6 × 4-9 mm, largamente ovais, agudos; filetes glabros. Flores pistiladas 0,8-1,4 cm compr.; botões 3-6 mm compr., ovoides; pedicelo 1-1,4 cm compr; brácteas 8-12 $\times 2,4-3 \mathrm{~mm}$, lanceoladas, inteiras, acuminadas, vináceas a roxeadas, persistentes; cálice dialissépalo, sépalas $0,7-1 \times 0,3-0,5 \mathrm{~mm}$, lanceoladas, agudas, vináceas com margem amarelada; ovário $2,1-3 \times$ 


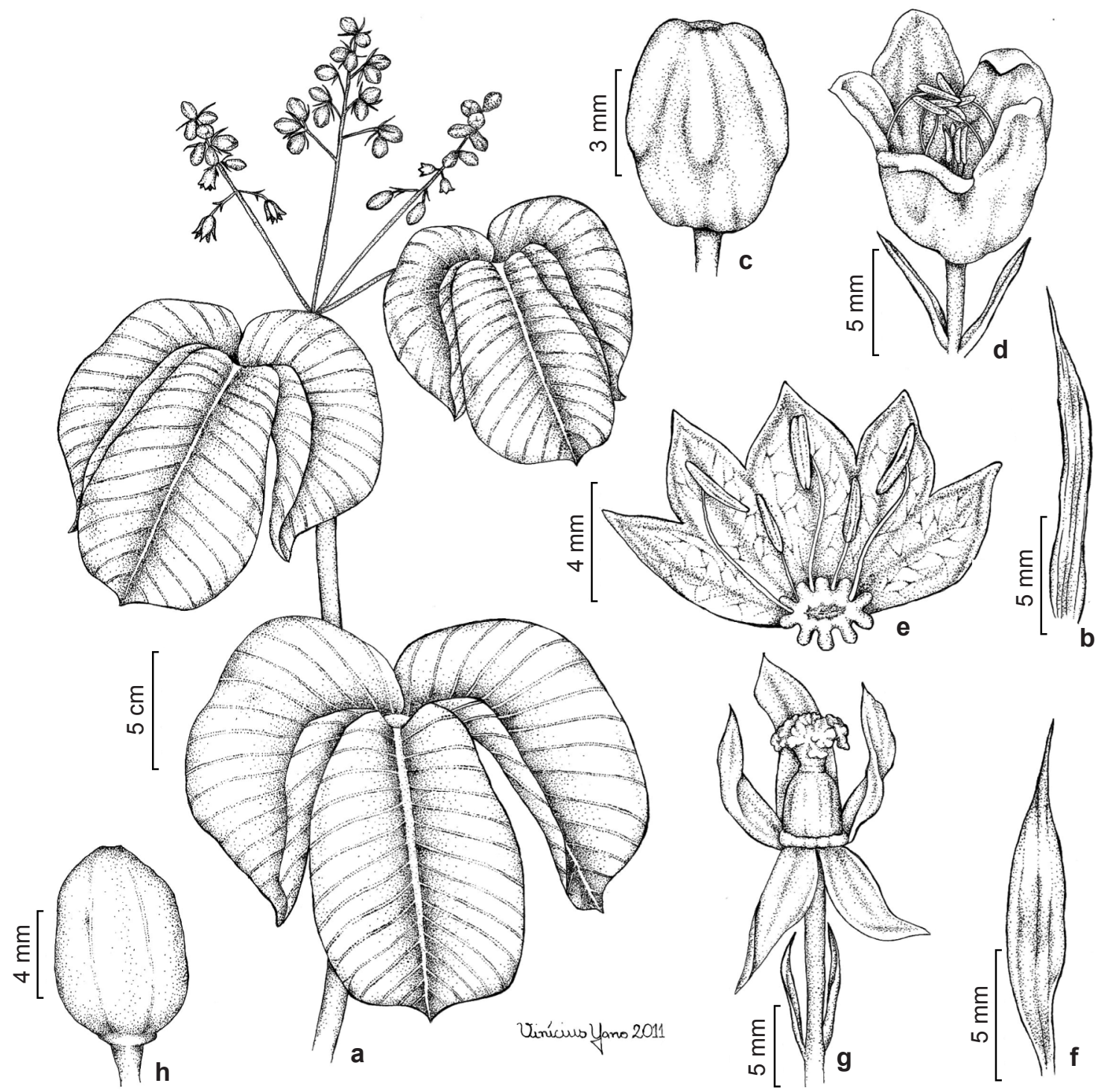

Figura 4 - Manihot irwinii. a. ramo florido; b. bráctea estaminada; c. botão estaminado; d. flor estaminada; e. flor estaminada aberta; f. bráctea pistilada; g. flor pistilada; h. fruto (M.J. Silva 3372).

Figure 4 - Manihot irwinii. a. flowering branch; b. staminate bract; c. staminate bud; d. staminate flower; e. staminate flower opened out; f. pistillate bract; g. pistillate flower; h. fruit (M.J. Silva 3372).

1,5-2 mm, globoide; disco alaranjado. Cápsulas 16-17 $\times 12-14 \mathrm{~mm}$, globoides, costadas, glabras, verdeescuras a verde-arroxeados. Sementes 8-10×4-5 mm, oblongoides, creme-cinéreas com máculas marrons.

Material examinado selecionado: caminho para a Pedra Goiana, 9.XII.2009, fl., A.M. Teles 658 (UFG); 30.X.2010, fl., M.J. Silva 3138, 3139 (UFG); distrito de Mirandópolis, fazenda do Rildo Nogueira, 27.XI.2010, fl., M.J. Silva 3194, 3198 (UFG); imediações da primeira cancela que leva a sede do PESD, $16^{\circ} 4$ ' $46,9^{\prime}$ 'S, 50¹1'28,4”'W, 985 m, 29.I.2011, fl. e fr., M.J. Silva 3372
(UFG); 4 Km acima do Córrego Piçarrão, 16 04'17,4”'S, $50^{\circ} 11$ '26,1”W, 993 m, 30.IV.2011, fl. e fr., J.E.C. Júnior 15, 18 (UFG); após Areal, $16^{\circ} 04^{\prime} 00,9^{\prime \prime} \mathrm{S}, 50^{\circ} 10^{\prime} 8,9^{\prime \prime} \mathrm{W}$ 953 m, 28.V.2011, fr., J.E.C. Júnior 51 (UFG).

Manihot irwinii é uma espécie endêmica do estado de Goiás, sendo referida para os municípios de Corumbá de Goiás e Goiás por Rogers \& Appan (1973) e primeiramente neste trabalho para Mossâmedes. No PESD, foi encontrada no Cerrado s.s. próximo a afloramentos de arenito em solos argilo-pedregosos ou pedregosos. 
As folhas com os ápices dos lobos cuspidados e com nervuras secundárias subparalelas e as flores de ambos os sexos com cálices vináceos com margem dos lobos amareladas torna esta espécie diferenciada das demais, especialmente de $M$. mossamedensis Taub. e M. sparsifolia Pohl com a qual compartilha as folhas com nervuras principais rosadas a vináceas e espessas e os frutos costados. Floresce entre outubro e abril e frutifica de janeiro à maio.

4. Manihot mossamedensis Taub., Bot. Jahrb. Syst. 21: 442.1896.

Fig. 5

Arbusto 1,5-4,3 m alt., ereto ou pendentes; látex amarelado; ramos tomentosos; estípulas caducas. Pecíolo 2,1-7,5 cm compr.; lâmina foliar (3)5-7-lobada, coriácea, face abaxial tomentosa, lobos $8-11 \times 3,8-5 \mathrm{~cm}$, oblongo-elípticos a obovais, inteiros, sobrepostos basalmente, ápice cuspidado, nervuras principais espessas, róseas a vináceas, as secundárias delgadas, arqueadas, amareladas. Racemo-espiciforme 5-8 cm compr., bissexuado, pendente, congesto. Flores estaminadas 7,5-9 mm compr.; botões 5-7 mm compr., ovoides a elipsoides; pedicelo 1-2 mm compr.; brácteas $6-16 \times 2-5 \mathrm{~mm}$, oval-lanceoladas, inteiras, agudas, tomentosas, amareladas, persistentes; cálice gamossépalo $6,5-7 \times 3-5 \mathrm{~mm}$, longamente campanulado, verde-amarelado, lobos 3-5 × 4-6 $\mathrm{mm}$, ovais, agudos; filetes pubescentes. Flores pistiladas 1,6-2,5 cm compr.; botões $6-8 \mathrm{~mm}$ compr., ovoides; pedicelo $0,8-1 \mathrm{~cm}$ compr.; brácteas 5-14 × 2-4 mm, oval-lanceoladas, inteiras, acuminadas, tomentosas, amareladas, persistentes; cálice dialissépalo, sépalas $0,8-1,5 \times 0,5-0,7 \mathrm{~cm}$, lanceoladas, agudas, verde-amareladas; ovário 2-5 $\times 1,5-4 \mathrm{~mm}$, globoide; disco alaranjado. Cápsulas 11-15 × 13-15 mm, globoides a oblongoides, costadas, tomentosas, verde-opacas com costas vináceas. Sementes 12-13×5-6 mm, oblongoides, cinéreas com máculas negras.

Material examinado selecionado: arredores caixa d'água da Reserva Biológica Professor José Ângelo Rizzo, 29.V.2010, fr., A.M. Teles 856 (UFG); cerca de 700 m acima do Córrego do Piçarrão 27.V.2011, fl. e fr., M.J. Silva 3527, 3528 (UFG); início da mata seca em direção ao Córrego do Piçarrão, $16^{\circ} 04^{\prime} 0,08^{\prime \prime} \mathrm{S}, 50^{\circ} 10^{\prime} 47,1^{\prime \prime} \mathrm{W}$, 997 m, 27.V.2011, fr., J.E.C. Júnior 36, 37 (UFG).

Espécie endêmica do estado de Goiás, sendo registrada para os municípios de Formosa, Goiás e Mossâmedes (Rogers \& Appan 1973) crescendo associada a floresta estacional em altitudes de até 997 metros. No PESD foi encontrado acima do Córrego do Piçarrão e nos arredores da nascente de captação, em ambientes semelhantes aos encontrados nas outras localidades de sua ocorrência.

Distinguível das demais espécies pelas folhas (3)5-7 lobadas, racemo-espiciformes congestos e pendentes, brácteas de ambas as flores amplas (5-16 × 2-5 mm), oval-lanceoladas e amareladas, filetes pubescentes, cápsulas costadas e tomentosas. Relaciona-se morfologicamente com Manihot sparsifolia e $M$. irwinii conforme discutido no comentário desta última. Floresce e frutifica entre abril e junho.

5. Manihot oligantha Pax, Pflanzenr. 147, 2: 53. 1910.

Fig. 6

Subarbusto $15-25 \mathrm{~cm}$ alt., cespitoso, caule praticamente subterrâneo, ereto; látex hialino; ramos glabros; estípulas persistentes. Pecíolo 2-4,5 cm compr.; lâmina foliar 5-lobada, membranácea, face abaxial glabra; lobos 3,6-4 $\times 0,6-0,8 \mathrm{~cm}$, lineares, inteiros, não sobrepostos basalmente, ápice agudo, nervuras delgadas, verde-amareladas, as secundárias subpararelas. Racemo 1,5-3 cm compr., unissexuado, pendente, laxo. Flores estaminadas 11-16 mm compr.; botões 5-8 mm compr., oblongoides; pedicelo $1-3$ mm compr.; brácteas 6-8 $81-2 \mathrm{~mm}$, lanceoladas, laciniadas, agudas, glabras, amarelo-esverdeadas, persistentes; cálice gamossépalo 10-13 × 3-6 mm, campanulado, creme-alvacento, lobos 4-6 $\times 1-2 \mathrm{~mm}$, ovais, agudos; filetes glabros. Flores pistiladas $12-19 \mathrm{~mm}$ compr.; botões $6-10 \mathrm{~mm}$ compr., elipsoides; pedicelo 2-4 mm compr.; brácteas 4-6 × 0,8-1 mm, lanceoladas, laciniadas, acuminadas, glabras, amarelo-esverdeadas, persistentes; cálice gamossépalo 8-15 × 6-9 $\mathrm{mm}$, campanulado, creme-amarelado, lobos 5,5-7 $\times 2-3 \mathrm{~mm}$, lanceolados, agudos; ovário $2-3 \times$ 1,5-2 mm, oblongoide; disco amarelado. Frutos e sementes não vistos.

Material examinado selecionado: imediações do Areal, 29.X.2010, fl., M.J. Silva 3128 (UFG); 29.XI.2011, fl., M.J. Silva 3930 (UFG).

Manihot oligantha é uma espécie endêmica do estado de Goiás, onde habita os campos sujos (Rogers \& Appan 1973), ambiente este onde também foi coletada neste estudo, nas imediações da localidade areal. O porte pequeno (15-25 cm alt.) com caule praticamente subterrâneo, associado às estípulas persistentes e as inflorescências unissexuadas auxiliam a identificação desta espécie e a diferencia das demais estudadas. Coletada com flores em outubro e novembro. 

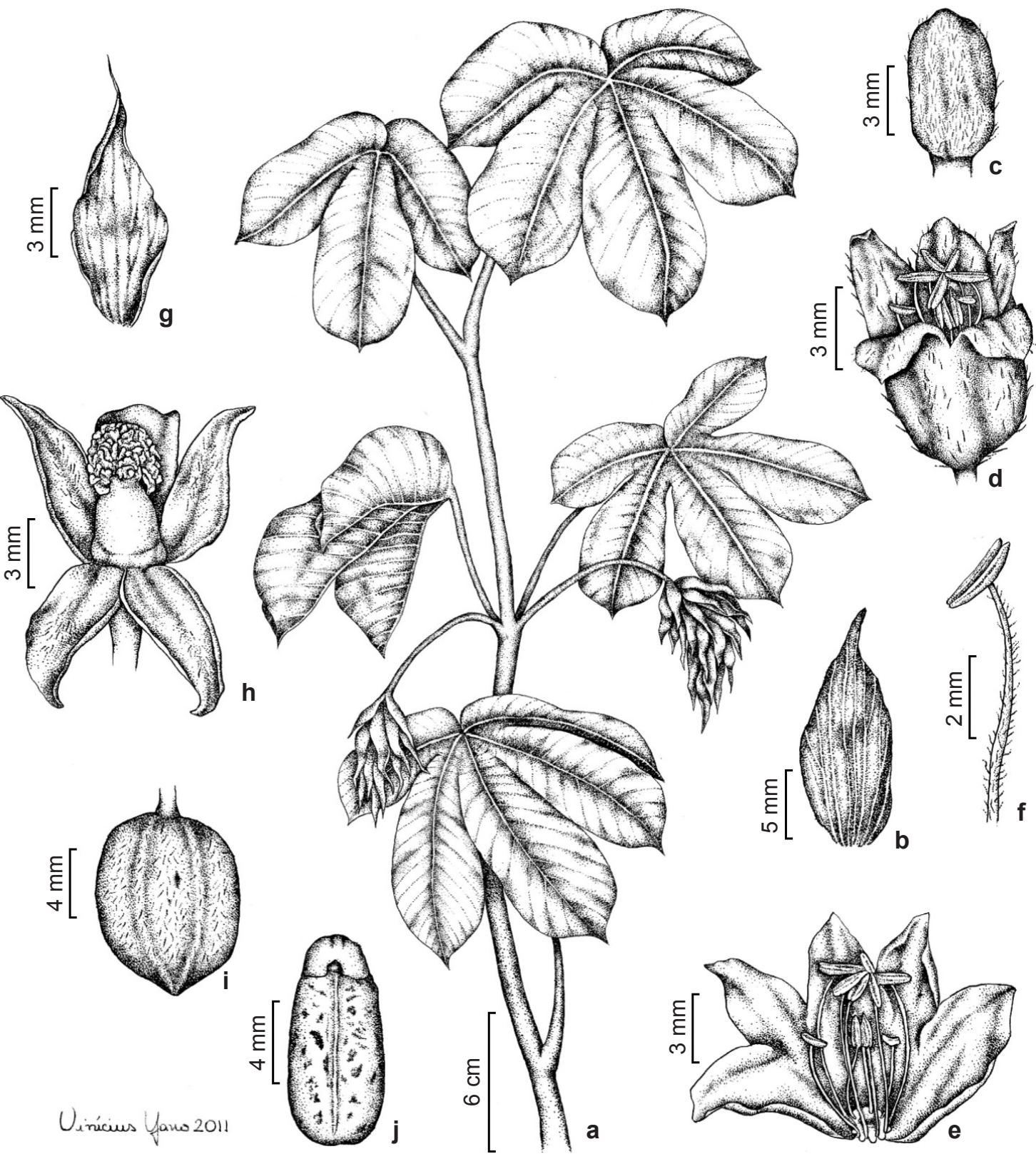

Figura 5 - Manihot mossamedensis. a. ramo florido; b. bráctea estaminada; c. botão estaminado; d. flor estaminada; e. flor estaminada aberta; f. estame; g. bráctea pistilada; h. flor pistilada; i. fruto; j. semente (M.J. Silva 3528).

Figure 5 - Manihot mossamedensis. a. flowering branch; b. staminate bract; c. staminate bud; d. staminate flower; e. staminate flower opened out; f. stamen; g. pistillate bract; h. pistillate flower; i. fruit; j. seed (M.J. Silva 3528).

6. Manihot paviifolia Pohl, Pl. Bras. Icon. Descr. 1: 52, t. 45.1827.

Fig. 7

Subarbusto 0,6-0,9 $\mathrm{m}$ alt., ereto, látex amarelado; ramos glabros; estípulas caducas. Pecíolo 2-5 cm compr.; lâmina foliar 3-5-lobadas, membranácea, face abaxial glabra, lobos 5,5-10 $\times 1,8-5 \mathrm{~cm}$, estreitamente elípticos, inteiros, não sobrepostos basalmente, ápice caudado, nervuras amarelo-esbranquiçadas, delgadas. Racemo 3-8 cm compr., bissexuado, pendente, laxo. Flores estaminadas 7-15,2 mm compr.; botões 4,5-9 mm compr., elipsoides; pedicelo 1-1,2 mm compr.; brácteas $11-16 \times 2-5 \mathrm{~mm}$, lanceoladas, inteiras, raro laciniadas, agudas, verde-amareladas a 

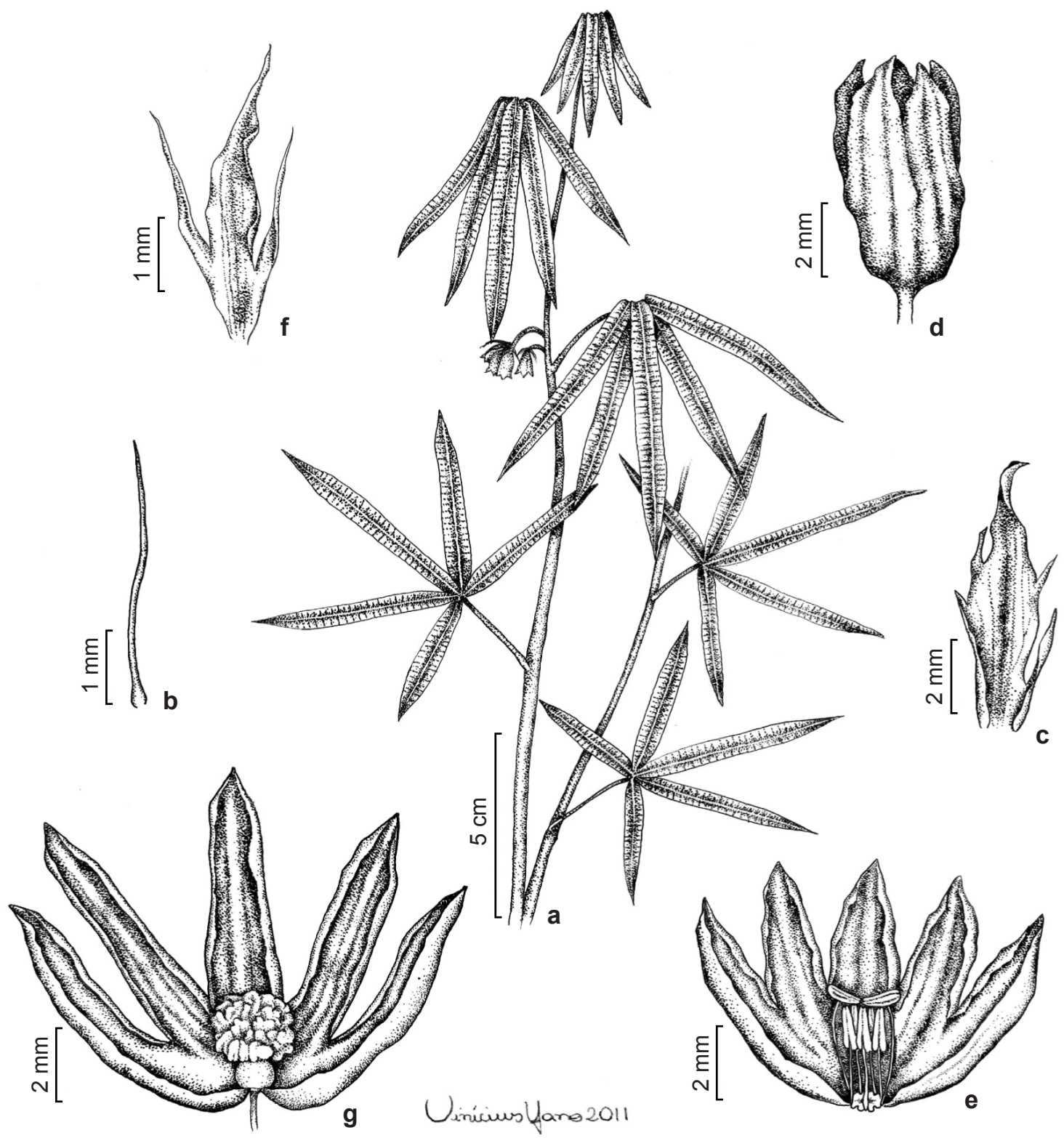

Figura 6 - Manihot oligantha. a. ramo florido; b. estípula; c. bráctea estaminada; d. flor estaminada. e. flor estaminada aberta; f. bráctea pistilada; g. flor pistilada aberta (M.J. Silva 3128).

Figure 6 - Manihot oligantha. a. flowering branch; b. stipule; c. staminate bract; d. staminate flower; e. staminate flower opened out; f. pistillate bract; g. pistillate flower opened out (M.J. Silva 3128).

vináceas, persistentes; cálice gamossépalo 6-14 $\times 3-5 \mathrm{~mm}$, campanulado, verde com máculas vináceas, lobos 3-5 × 4-6 mm, ovais, agudos; filetes glabros. Flores pistiladas $11-16 \mathrm{~mm}$ compr.; botões 4-6 mm compr., oblongoides; pedicelo 4-6 mm compr.; brácteas 8-10 × 2-3 mm, lanceoladas, inteiras, agudas, verde-amareladas, persistentes; cálice dialissépalo, sépalas 7-10×
3-4 mm, lanceoladas, agudas, verde-amareladas com máculas vináceas; ovário 3-4 × 1-2 mm, oblongoide; disco amarelo. Cápsulas 8-9 × 7-8,5 $\mathrm{mm}$, globoides, não costadas, glabras, verde-claras. Sementes 7-8,5 × 3-3,5 mm, oblongoides, marfins com discretas máculas alvas.

Material examinado selecionado: arredores do Areal, 29.X.2010, fl., M.J.Silva 3126 (UFG); próximo à sede, 

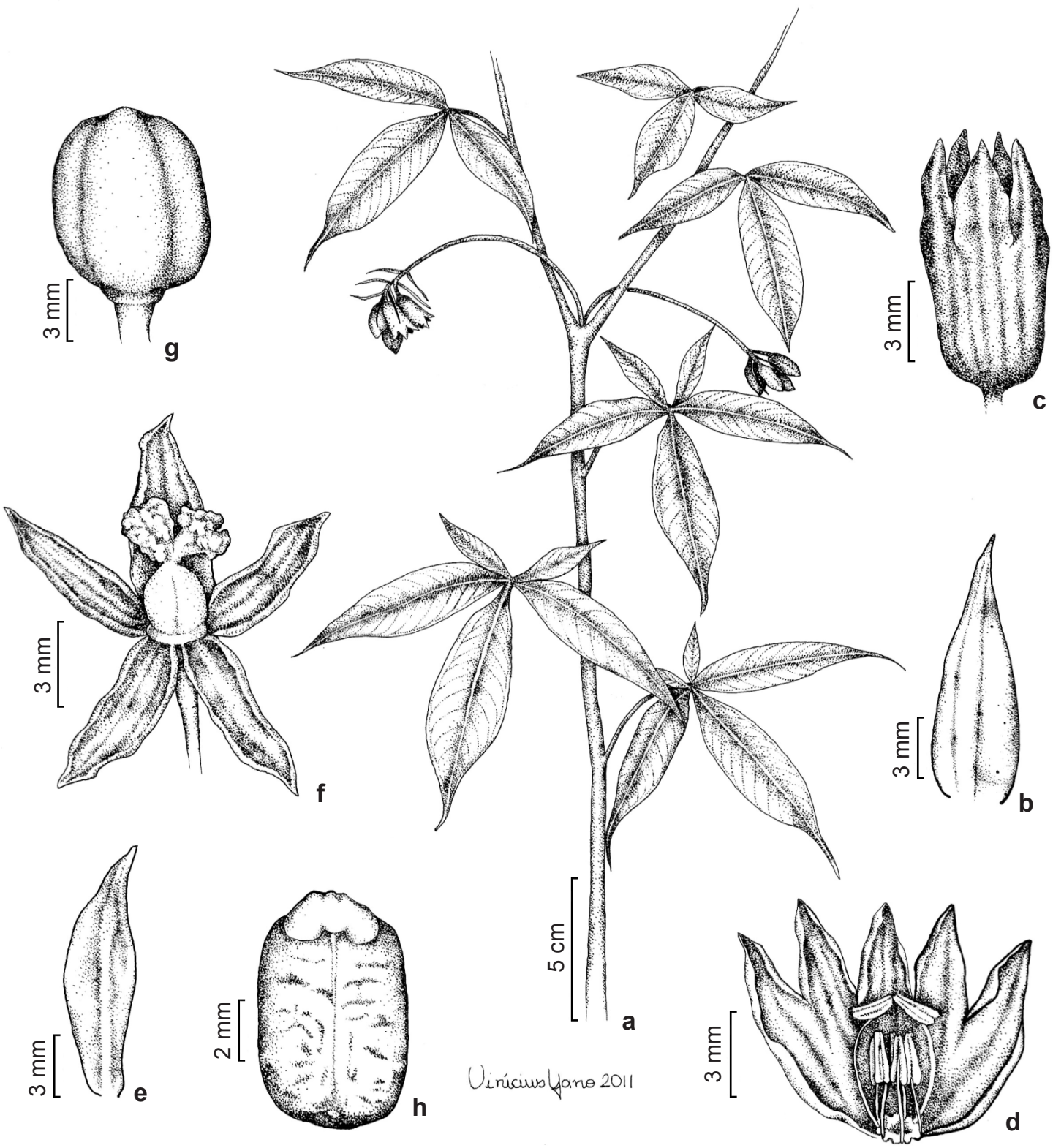

Figura 7 - Manihot paviifolia. a. ramo florido; b. bráctea estaminada; c. flor estaminada; d. flor estaminada aberta; e. bráctea pistilada; f. flor pistilada; g. fruto; h. semente (M.J. Silva 3328).

Figure 7 - Manihot paviifolia. a. flowering branch; b. staminate bract; c. staminate flower; d. staminate flower opened out; e. pistillate bract; f. pistillate flower; g. fruit; h. seed (M.J. Silva 3328).

30.X.2010, fl., M.J. Silva 3146 (UFG); após a floresta estacional semidecidual, $16^{\circ} 5$ ' 21,2'S, $50^{\circ} 11^{\prime} \mathrm{W}, 788 \mathrm{~m}$, 25.XI.2010, fl., M.J. Silva 3157, 3158 (UFG); arredores da Pedra Goiana, 27.XI.2010, fl., M.J. Silva 3197 (UFG); acima da floresta estacional semidecidual, $16^{\circ} 5^{\prime} 5,5^{\prime}$ 'S, $50^{\circ} 10^{\prime} 45,8^{\prime \prime} \mathrm{W}, 831 \mathrm{~m}, 28 . \mathrm{I} .2011$, fl. e fr., M.J. Silva 3328 (UFG); 28.X.2011, fl., M.J. Silva 3904 (UFG); Flanco Nordeste do PESD, 16'4'39,7'S, 50¹1'28'”, 995 m, 30.IV.2011, fl., J.E.C. Júnior 20 (UFG).
Material adicional: BRASIL: Goiás, Pirenópolis, 8.I.1999, fl., H.D. Ferreira 3670 (UFG).

Endêmica do estado de Goiás (municípios de Corumbá de Goiás, Goiás e Mossâmedes) conforme Rogers \& Appan (1973). No PESD é frequente em cerrado s.s., cerrado rupestre e campos sujos.

Entre as espécies estudadas, Manihot xavantinensis D.J. Rogers \& Appan é a que 
mais se assemelha a $M$. paviifolia por ambas compartilharem os ramos e face abaxial das folhas glabras, folhas predominantemente 3-lobadas com lobos estreitamente elípticos e nervuras delgadas amareladas. Entretanto, M. paviifolia possui lobos foliares com ápice caudado (vs. com ápice agudo a acuminado em $M$. xavantinensis), brácteas estaminadas $11-16 \times 2-5 \mathrm{~mm}(v s .1-7 \times 1-2,5 \mathrm{~mm})$, pedicelo da flor pistilada com 4-6 mm compr. (vs. 10-12 mm compr.). Coletada com flores e frutos entre outubro e janeiro.

7. Manihot pentaphylla Pohl, Pl. Bras. Ic. et. Descr. 1: 53. t. 46. 1827.

Subarbustos a arbustos 0,7-1,2 m alt., prostrados a subdecumbentes ou eretos; látex amarelado; ramos glabros; estípulas caducas. Pecíolo 4-5,5 cm compr.; lâmina foliar 5-lobada, membranácea, lobos 5-12 × 0,2-1 cm, lineares, inteiros, não sobrepostos basalmente, ápice acuminado, nervuras delgadas, amareladas. Racemo 2,5-12 cm compr., bissexuado, subereto a pendente, laxo ou congesto. Flores estaminadas
9-18 mm compr.; botões 4-6 mm compr., elipsoides; pedicelo 4-10 mm compr.; brácteas 5-9 × 1-3 mm, lanceoladas, inteiras a laciniadas, acuminadas, verde-amareladas, persistentes; cálice gamossépalo 8-12 × 4-6 mm, campanulado, creme-esverdeado, lobos 4-6 6 4-5 mm, triangulares a ovais, agudo; filetes glabros. Flores pistiladas 9,2-17,6 mm compr.; botões 4-5 mm compr., elipsoides; pedicelo 1,2-1,6 mm compr.; brácteas 1,5-6 × 0,4-2 mm, lanceoladas, inteiras a laciniadas, acuminadas, verde-amareladas, persistentes; cálice dialissépalo, sépalas 8-16 × 3-7 mm, lanceoladas, agudas, verde-amareladas; ovário 2-3 × 1-2,5 mm, globoide; disco amarelado. Cápsulas 0,9-1,1 ×0,8-1,3 cm, oblongoides, não costadas, glabras, verde-glaucente. Sementes 4-5 $\times$ 7-8 mm, oblongoides, cinéreas com máculas marrons.

Manihot pentaphylla, de acordo com Rogers \& Appan (1973), compreende quatro subespécies, duas das quais encontradas no PESD, conforme a chave abaixo:

1. Subarbusto prostrado a decumbente com até $50 \mathrm{~cm}$ alt.; lobos foliares 2-3 mm larg.; inflorescências com até 8 flores 7b. M. pentaphylla subsp. tenuifolia

1'. Arbusto ereto 0,7-1,8 m alt.; lobos foliares 6-10 mm larg.; inflorescências com mais de 8 flores 7a. M. pentaphylla subsp. pentaphylla

7a. Manihot pentaphylla Pohl subsp. pentaphylla Fig. 8 Material examinado selecionado: distrito de Mirandópolis, imediações da Fazenda do Sr. Rildo, 25.XI.2010, fl. M.J. Silva 3191, 3193, 3195 (UFG); transição mata seca e cerrado na subida da estrada que leva à sede, $16^{\circ} 5$ '21,2"S, 50¹1'51'W, 788 m, 28.I.2011, fl. e fr., M.J. Silva 3332, 3334, 3336, 3339 (UFG); vertente esquerda do Corrégo do Piçarrão, 29.I.2011, fl. e fr., M.J. Silva 3381 (UFG); após o areal, 26.III.2011, fr., M.J. Silva 3504 (UFG).

Manihot pentaphylla subsp. pentaphylla é um táxon restrito ao estado de Goiás, com registro de coleta às Serras Dourada e dos Pireneus e proximidades de Corumbá de Goiás (Rogers \& Appan 1973). No PESD é frequente no cerrado S.S., no cerrado rupestre e em clareiras da mata seca acima do córrego do Piçarrão.

Entre os táxons estudados com folhas de lobos lineares, $M$. pentaphylla subsp. pentaphylla relacionase morfologicamente a $M$. pentaphylla subsp. tenuifolia, por ambas compartilharem as estípulas caducas, folhas 5-lobadas com lobos sobrepostos basalmente e estames glabros. Porém $M$. pentaphylla subsp. pentaphylla apresenta hábito arbustivo e ereto (vs. subarbustivo e prostrado a subdecumbente em M. pentaphylla subsp. tenuifolia), lobos foliares com 6-10 mm larg. (vs. 2-3 mm larg.), racemos laxos, com mais que oito flores ( $v s$. congestos, com menos que oito flores) e brácteas inteiras a raro ligeiramente laciniadas (vs. conspicuamente laciniadas). Floresce e frutifica de novembro a março.

7b. Manihot pentaphylla subsp. tenuifolia (Pohl) D.J. Rogers \& Appan, Fl. Neotrop. Monogr. 13: 153. 1973. Manihot tenuifolia Pohl, Pl. Bras. Ic. et. Descr. 1: 38.1827

Fig. 9

Material examinado selecionado: entre os córregos do Cafundó e Piçarrão, 17.III.1994, fl., J.A Rizzo 11105 (UFG); no morro da antena de telefonia cancela que leva a sede do PESD, 29.I.11, fl., M.J. Silva 3377, 3378 (UFG); cerrado acima da mata seca em direção a sede do PESD, 28.I.2011, fl. e fr., M.J. Silva 3338, 3339, 3143 (UFG); 29.IX.2011, fl. J.E.C. Júnior 65, 70 (UFG), 1605'5,5”S, 50¹0'45,8”W, 831 m, 28.X.2011, fl. e fr., M.J. Silva 3903 (UFG); após o Areal, 16³'43,6”S, 50¹0'06,7'”W, 1024 m, 26.III.2011, fr., M.J. Silva 3507 (UFG). 

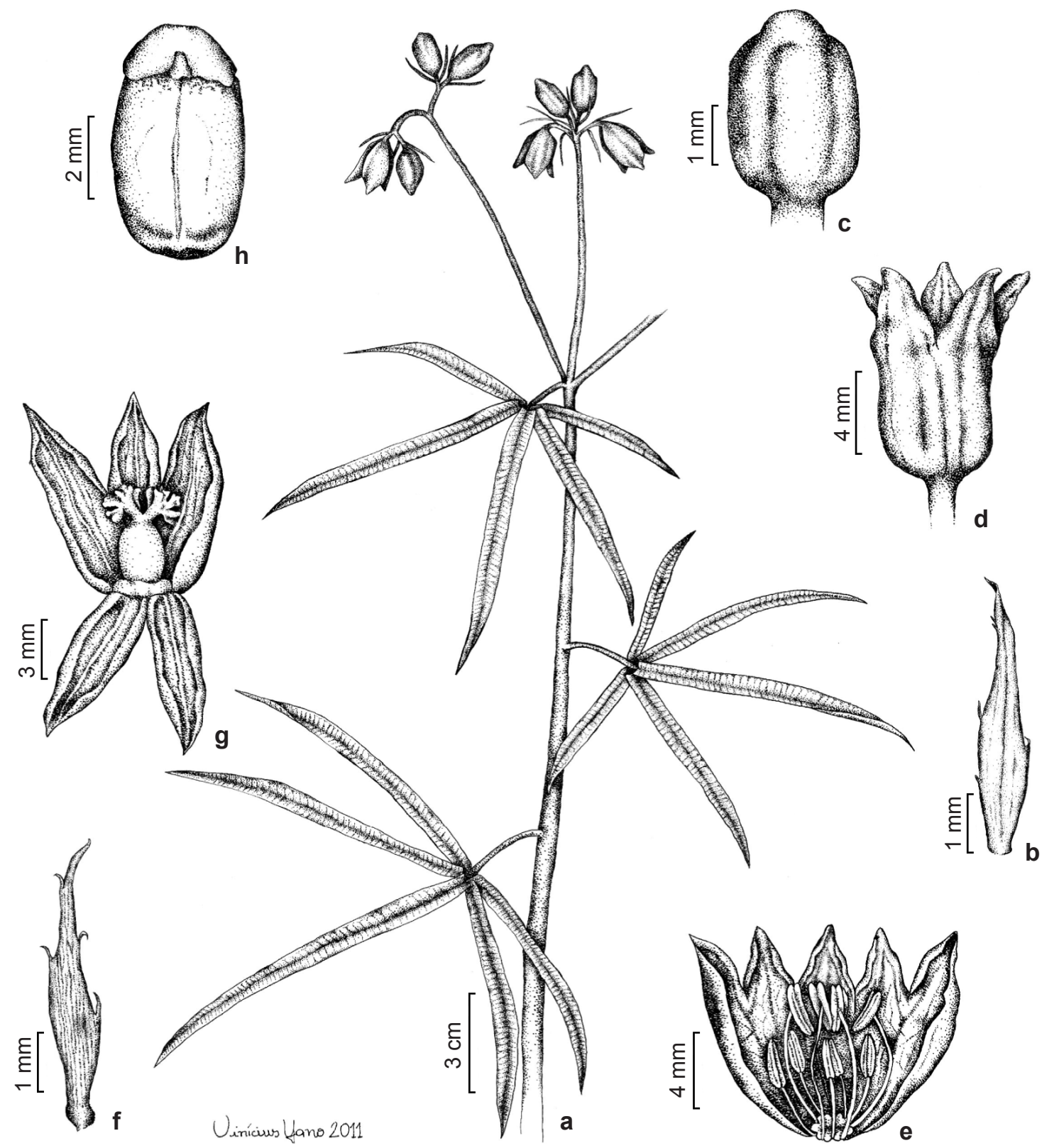

Figura 8 - Manihot pentaphylla subsp. pentaphylla. a. ramo florido; b. bráctea estaminada; c. botão estaminado; d. flor estaminada; e. flor estaminada aberta; f. bráctea pistilada; g. flor pistilada; h. semente (M.J. Silva 3332).

Figure 8-Manihot pentaphylla subsp. pentaphylla. a. flowering branch; b. staminate bract; c. staminate bud; d. staminate flower; e. staminate flower opened out; f. pistillate bract; g. pistillate flower; h. seed (M.J. Silva 3332).

Material adicional: BRASIL; GOIÁS: Santa Bárbara, Serra da Jibóia, 15.II.2011, fl., M.J. Silva 3387 (UFG).

Registrada nos estados de Goiás e Pará (Rogers \& Appan 1973), no primeiro referenciada inicialmente para a Serra da Jibóia. Habita desde os cerrados rupestres, onde se mostra prostrada e com ramos bastante difusos, até o cerrado
S.s., onde exibe um porte subdecumbente. No PESD é frequente nos cerrados rupestres após a mata seca acima do Córrego do Piçarrão, nas redondezas do Mirante e após o Areal em campos sujos, sobre solos litólicos ou arenosos. Sua floração inicia-se em outubro e frutifica entre novembro e março. 

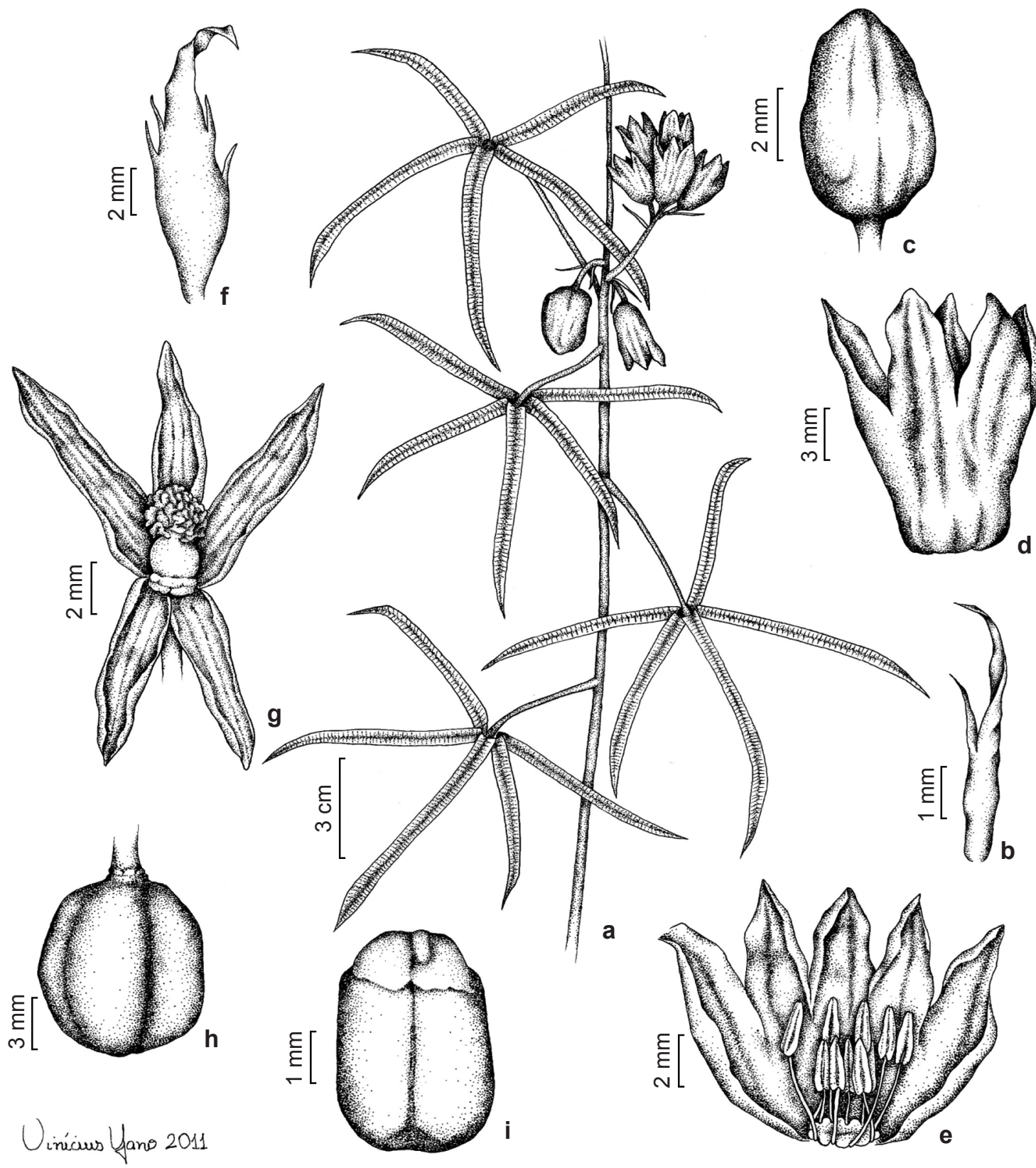

Figura 9 - Manihot pentaphylla subsp. tenuifolia. a. ramo florido; b. bráctea estaminada; c. botão estaminado; d. flor estaminada; e. flor estaminada aberta; f. bráctea pistilada; g. flor pistilada; h. fruto; i. semente (M.J. Silva 3903). Figure 9 - Manihot pentaphylla subsp. tenuifolia. a. flowering branch; b. staminate bract; c. staminate bud; d. staminate flower; e. staminate flower opened out; f. pistillate bract; g. pistillate flower; h. fruit; i. seed (M.J. Silva 3903).

8. Manihot sparsifolia Pohl, Pl. Bras. Ic. et. Descr. 1: 26, pl. 20. 1827.

Fig. 10

Subarbusto $15-60 \mathrm{~cm}$ alt., prostado, látex hialino; ramos glabros; estípulas caducas. Pecíolo 3-13 cm compr.; lâmina foliar 3-lobada, coriácea, face abaxial indumentada, lobos 7-13 × 3-6,5 cm, oblongo-elípticos a oblongo-lanceolados, inteiros, não sobrepostos basalmente, ápice agudo, nervuras primárias espessas, róseas a vináceas, as secundárias delgadas, arqueadas, róseas. Racemo-espiciforme 2,8-5,0 cm compr., bissexuado, ereto, congesto. Flores estaminadas 5-12 mm compr.; botões 4-5 mm compr., globoides a ovoides; pedicelos 1-2 mm compr.; brácteas 1-2 × 1-1,5 mm, oblongo-ovais, 


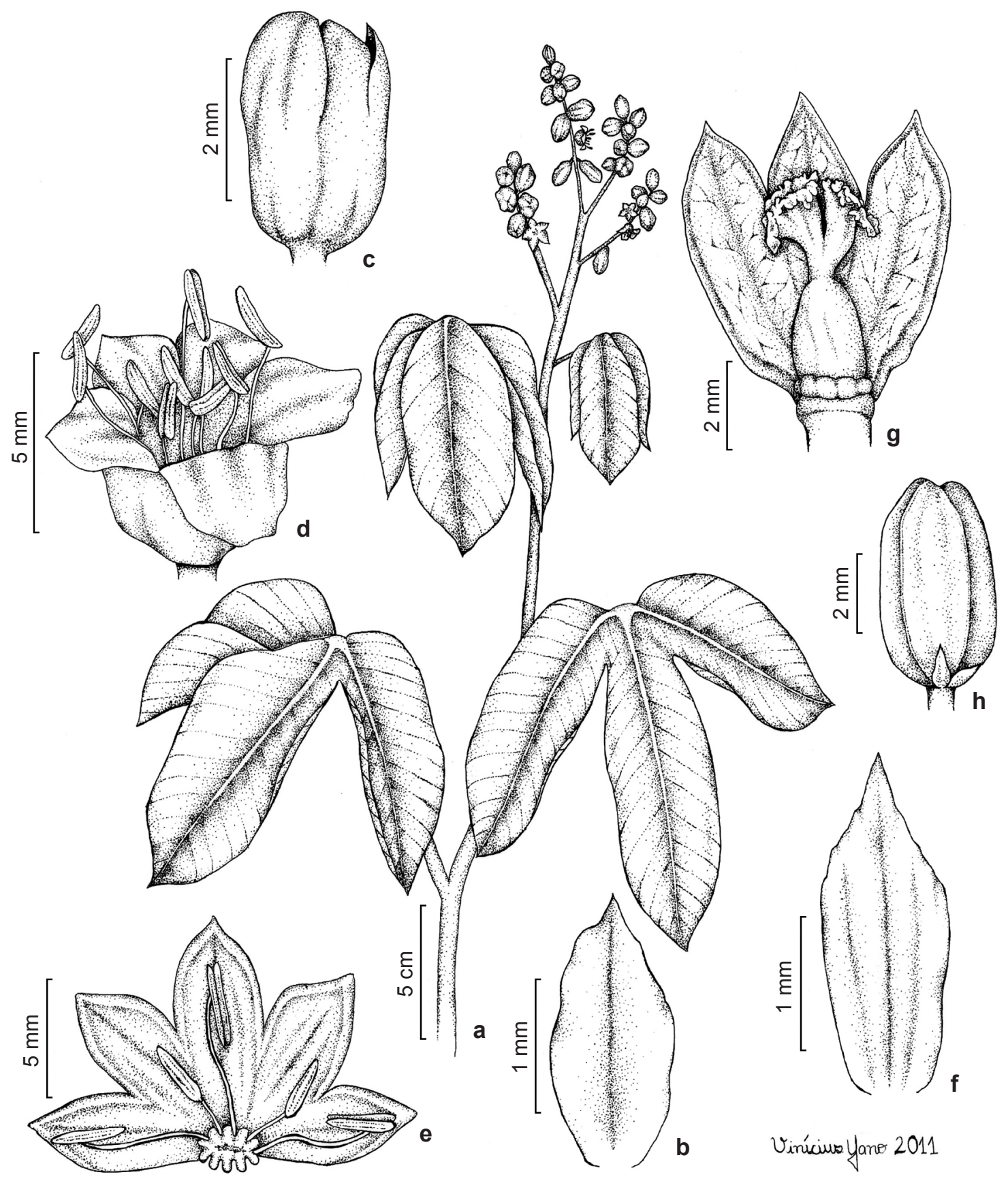

Figura 10 - Manihot sparsifolia. a. ramo florido; b. bráctea estaminada; c. botão estaminado; d. flor estaminada; e. flor estaminada aberta; f. bráctea pistilada; g. flor pistilada aberta; h. fruto (M.J. Silva 3377).

Figure 10 - Manihot sparsifolia. a. flowering branch; b. staminate bract; c. staminate bud; d. staminate flower; e. staminate flower opened out; f. pistillate bract; g. pistillate flower opened out; h. fruit (M.J. Silva 3377).

inteiras, agudas, persistentes; cálice gamossépalo 4-10 $\times$ 5-6 mm, campanulado, verde-amarelado, lobos 4-6 $\times 3-5 \mathrm{~mm}$, ovais, agudo; filetes glabros. Flores pistiladas 4-8,5 mm compr.; botões $4-6 \mathrm{~mm}$ compr., oblongoides; pedicelo 2-3,5 mm compr.; brácteas 2-3 $\times 1-1,2 \mathrm{~mm}$, oblongas, inteiras, agudas, persistentes; cálice gamossépalo 4-5 × 2,5-5 mm, campanulado, verde-opaco a glauco com extremidades rosadas, 
lobos 2-3 × 1-2 mm, ovais, agudos; ovário 3-4 × 2-2,2 mm, subgloboide; disco amarelado. Cápsulas 10-12 × 12-15 mm, globoides, costadas, verdeescuras com máculas arroxeadas. Sementes 7-7,4× 4 $4,5 \mathrm{~mm}$, oblongoides, cinza-esbranquiçadas.

Material examinado selecionado: estrada para o Mirante 29.X.2010, fl., M.J. Silva 3125 (UFG); flanco Nordeste da Reserva, 30.X.2010, fl. e fr., M.J. Silva 3140 (UFG); 26.XI.2010, fl. e fr., M.J. Silva 3170, 3177, 3179 (UFG); nos arredores da sede, 30.X.2010, fl., M.J. Silva 3143 (UFG); arredorres da antena de transmissão, 29.I.2011, fl. e fr, M.J. Silva 3377, 3378 (UFG); após o Areal, 28.V.2011, fl., J.E.C. Júnior 39,40,41 (UFG); imediações da rampa para asa-delta, 28.V.2011, fl. e fr., J.E.C. Júnior 53 (UFG). Material adicional: BRASIL. GOIÁS: Itaberaí, GO-070 Itaberaí-Goiás, 22 km antes de Goiás Velho, 15.IV.1980, fr., A.C. Allem et al. 2651 (CEN); Uruaçu, GO-237 rumo a Niquelândia, $15^{\circ} 30^{\prime}$ 'S, $4^{\circ} 85^{\prime}$ '”'W, 3.III.1986, fl., A.C. Allem et al. 30386 (CEN, UB).

Espécie restrita ao Brasil Central (Goiás e Distrito Federal) (Rogers \& Appan 1973, Rodrigues 2007, Allem 1989a). Em Goiás ocorre na região central do estado (Corumbá de Goiás, Goiás, Mossâmedes e Uruaçu) crescendo sempre associada a cerrado rupestre ou campos limpos e rochosos sobre solos litólicos ou arenosos.

Manihot sparsifolia relaciona-se morfologicamente à $M$. mossamedensis e M. irwinii como já informado nos comentários destas últimas. No entanto, diferencia-se de ambas e é facilmente reconhecida por ser um subarbusto de até $70 \mathrm{~cm}$ alt., com ramos glabro, folhas 3-lobadas com lobos não sobrepostos basalmente, inflorescência ereta e congesta, flores pistiladas gamosépalas verde-opacas a glaucas com extremidades rosadas e estames glabros; enquanto M. mossamedensis e M.irwinii são arbustos com mais de 1,2 m alt., com flores pistiladas dialisépalas e ainda no primeiro as folhas são (3)5-7-lobadas, as inflorescências são pendentes e os ramos e os estames são indumentados, e no segundo os lobos das folhas são sobrepostos na base, a inflorescência é laxa e subpendente e ambas as flores são vináceas com extremidades amareladas. Floresce entre outubro e maio e frutifica de janeiro à maio.

9. Manihot xavantinensis D.J. Rogers \& Appan, Fl. Neotrop. Monogr. 13: 124.1973. Fig. 11

Subarbusto 0,7-1,2 $\mathrm{m}$ alt., ereto, látex amarelado; ramos glabros; estípulas caducas. Pecíolo 2-5,5 cm compr.; lâmina foliar 3-lobada, cartácea, face abaxial glabra, lobos 4-8,5 × 2-3 $\mathrm{cm}$, elípticos a estreitamente elípticos, inteiros, não sobrepostos basalmente, ápice agudo a curto acuminado, nervuras delgadas, amareladas. Racemo-espiciforme 1-5 cm compr., bissexuado, subereto a pendente, laxo. Flores estaminadas 9-12 mm compr.; botões 3-5 mm compr., ovoides; pedicelo 3-5 mm compr.; brácteas $4-7 \times 1-2,5$ $\mathrm{mm}$, lanceoladas, inteiras, acuminadas, amareloesverdeadas com máculas vináceas, persistentes; cálice gamossépalo 6-7 × 7-8 mm, campanulado, amarelado a verde opaco com discretas máculas vináceas, lobos 5-7 ×5-6 mm, ovais, agudo; filetes glabros. Flores pistiladas 12-13,3 mm compr.; botões 2-4 mm compr., elipsoides; pedicelo 1-1,2 cm compr.; brácteas 3-6 $\times 1-1,5 \mathrm{~mm}$, lanceoladas, inteiras a minutamente serreada, acuminadas, amarelo-esverdeadas com máculas vináceas, persistentes; cálice dialissépalo, sépalas 2-3 × 3-4 $\mathrm{mm}$, lanceoladas, agudas, amarelo-esverdeadas com discretas máculas vináceas; ovário 15-25 × 15-25 mm, globoide; disco amarelo. Cápsulas 9-11 × 7-9 $\mathrm{mm}$, oblongoides, não costadas, glabras, verdeclaras. Sementes $7-8 \times 4-5 \mathrm{~mm}$, oblongoides, cinéreo-amarrozandas com máculas negras.

Material examinado selecionado: arredores da Pedra Goiana, 25.XI.2010, fl. e fr., M.J. Silva 3167 (UFG); distrito de Mirandópolis, próximo à Fazenda de Rildo, 27.XI.2010, fl., M.J. Silva 3192 (UFG); transição mata seca e cerrado na estrada que leva à sede, $16^{\circ} 5^{\prime} 21,2^{\prime \prime}$, 50¹1'51'W, 788 m, 28.I.2011, fl. e fr., M.J. Silva 3327 (UFG); entre fendas de arenito, 29.I.2011, fl. e fr., M.J. Silva 3362 (UFG); próximo ao Areal, 26.III.2011, fr., M.J. Silva 3511 (UFG); sede do PESD, 16 ${ }^{\circ} 4^{\prime} 47,2^{\prime \prime}$, 50¹1’32,6”', 987 m, 30.IV.2011, J.E.C. Júnior 27 (UFG).

Até este trabalho Manihot xavantinensis tinha distribuição relatada apenas para áreas de cerrado de Mato Grosso e São Paulo (Rogers \& Appan 1973; Allem 1989a), sendo, portanto aqui citada para o estado de Goiás. Habita no cerrado rupestre e cerrado s.s. em solos litólicos, argilo-pedregosos ou em fendas de arenito.

Rogers \& Appan (1973) reconheceram para Manihot tripartita (Spreng.) Müll. Arg. quatro subespécies (M. tripartita subsp. tripartita (Spreng.) Müll. Arg., M. tripartita subsp humilis (Müll. Arg.) D.J. Rogers \& Appan, M. tripartita subsp. laciniosa (Pohl) D.J. Rogers \& Appan e $M$. tripartita subsp. vestita (S. Moore) D.J. Rogers \& Appan) diferenciadas principalmente pela largura e integridade dos lobos foliares, presença e tipo de indumento, tipo de venação e distribuição geográfica. Tais autores comentaram que $M$. tripartita subsp. laciniosa e M. tripartita subsp. vestita poderiam vir a ser espécies distintas haja vista serem bem diferenciadas morfologicamente. 

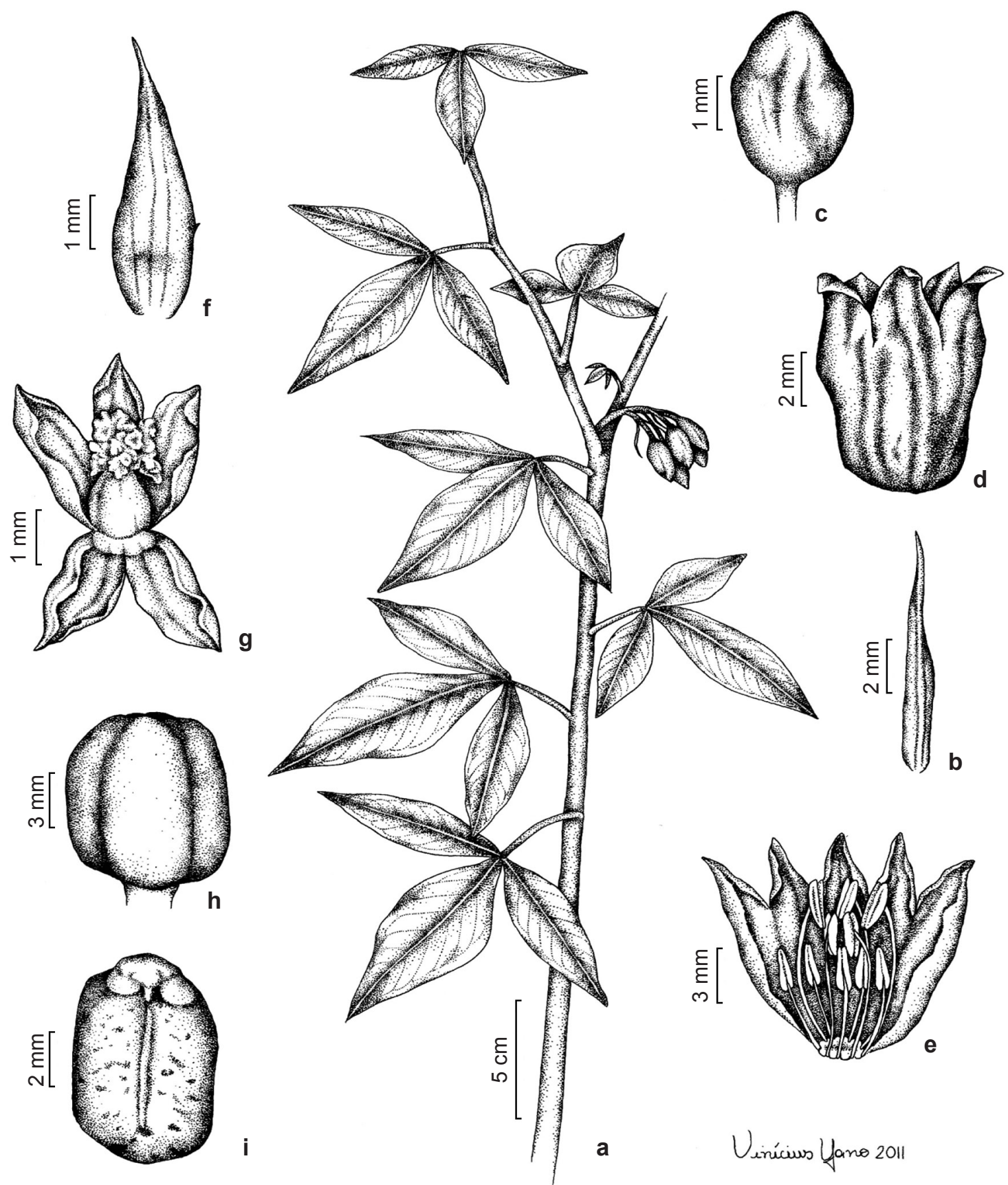

Figura 11 - Manihot xavantinensis. a. ramo florido; b. bráctea estaminada; c. botão estaminado; d. flor estaminada; e. flor estaminada aberta; f. bráctea pistilada; g. flor pistilada; h. fruto; i. semente (M.J. Silva 3327).

Figure 11 - Manihot xavantinensis. a. flowering branch; b. staminate bract; c. staminate bud; d. staminate flower; e. staminate flower opened out; f. pistillate bract; g. pistillate flower; h. fruit; i. seed (M.J. Silva 3327).

Allem (1989a) em sua revisão sobre Manihot sect. Quinquelobae reconheceu para M. tripartita as subespécies M. tripartita subsp. tripartita, M. tripartita subsp. invisa. e M. tripartita subsp. xavantinensis, com base no hábito, número de lobos foliares, profundidade das serrulas nas brácteas e bractéolas e coloração do caule e ramos e área geográfica.

Embora os autores acima tenham considerado M. xavantinensis como uma subespécie de $M$. tripartita optamos neste trabalho por considerar 
M. xavantinensis e $M$. tripartita como espécies distintas, haja vista esta última, embora possua uma ampla distribuição, é de fácil reconhecimento pelas brácteas largamente elípticas, róseas a amarelada e fortemente laciniadas, ramos jovens e inflorescências densamente curto-tomentosos, enquanto que $M$. xavantinensis é uma planta glabra com brácteas vináceas, lanceoladas, inteiras a muito raramente minutamente serreada. Manihot xavantinensis assemelha-se morfologicamente a $M$. paviifolia conforme já discutido no comentário desta última. Floresce e frutifica entre novembro e março.

\section{Agradecimentos}

Agradecemos ao Conselho Nacional de Desenvolvimento Científico e Tecnológico (CNPq) pela Bolsa de Iniciação Científica do primeiro autor (processo 108931-2011/7), ao Prof. Dr. Aristônio Magalhães Teles pelo apoio logístico por meio do projeto "Estudo Florístico do Parque Estadual da Serra Dourada" (CNPq processo 477620-2009/4), aos curadores dos herbários listados no texto pela hospitalidade e empréstimo das coleções, e aos revisores pelas sugestões ao texto.

\section{Referências}

Allem, A.C. 1989a. A revision of Manihot section Quinquelobae (Euphorbiaceae). Revista Brasileira de Biologia 49: 1-26.

Allem, A.C. 1989b. Four new species of Manihot (Euphorbiaceae) from Brazil. Revista Brasileira de Biologia 49: 649-662.

Allem, A.C. 1997. Notas taxonômicas sobre as tribos Phyllantheae, Dalechampieae e Manihoteae (Euphorbiaceae) no Rio Grande do Sul, Brasil. Iheringia, Série Botânica 22: 3-15.

Allem, A.C. 1999. A new species of Manihot (Euphorbiaceae) from Brazilian Amazon. International Journal of Plant Sciences 160: 181-187.

Allem, A.C. 2001.Three new infraespecific taxa of Manihot (Euphorbiaceae) from the Brazilian neotropics. Novon 11: 157-165.

Chacón, J.; Madriñán, S.; Debouck, D.; Rodriguez, F. \& Tohme, J. 2008. Phylogenetic patterns in the genus Manihot (Euphorbiaceae) inferred from analyses of nuclear and chloroplast DNA regions. Molecular Phylogenetics and Evolution 49: 260-267.

Cochrane, T.T.; Sanchez, L.G.; Azevedo, L.G.; Porras, J.A. \& Garver, C.L. 1985. Land in Tropical America. 3. vols. CIAT-EMBRAPA- CPAC, Cali. 714p.

Cordeiro, I. 1992. Flora da Serra do Cipó, Minas Gerais: Euphorbiaceae. Boletim de Botânica da Universidade de São Paulo 13: 169-217.
Duputié, A.; Salick, J. \& McKey, D. 2011. Evolutionary biogeography of Manihot (Euphorbiaceae), a rapidly radiating Neotropical genus restricted to dry environments. Journal of Biogeography 38: 1033-1043.

Köppen, W. 1948. Climatologia: com um estudio de los climas de la Terra. F.C.E., Ciudad de México. 87p.

Martins, M.L.L.; Carvalho, P.C.L. \& Amorim, A.M. 2011. A remarkable new Manihot (Euphorbiaceae) from the coastal sand plains of Sergipe, Brazil. Phytotaxa 32: 57-60.

Miller, P. 1754. The gardeners dictionary. $4^{\text {th }}$ ed. Vol. II. London.

Mori, S.A.; Mattos Silva, L.A.; Lisboa, G. \& Coradin, L. 1989. Manual de manejo do herbário fanerogâmico. Centro de Pesquisa do Cacau, Ilheus, CEPLAC. 103p.

Nassar, N.M.A. 1985. Manihot neusana Nassar: a new species native to Paraná, Brazil. Canadian Journal of Plant Science 65: 1097-1100.

Nassar, N.M.A.; Ribeiro, D.G.; Bomfim, N.N. \& Gomes, P.T.C. 2011. Manihot fortalezensis Nassar, Ribeiro, Bomfim et Gomes a new species of Manihot from Ceará, Brazil. Genetic Resources and Crop Evolution 58:831-835

Olsen, K.M. \& Schall, B.A. 1999. Evidence on the origin of cassava: Phylogeography of Manihot esculenta. Proceedings of the National Academy of Sciences of the United States of America. 96: 5586-5591.

Radford, A.E.; Dickison, W.C.; Massey, J.R. \& Bell, C.R. 1974. Vascular plant systematics. Harper \& Row, New York. 891p.

Rizzo, J.A. 1970. Contribuição ao conhecimento da flora de Goiás, área na Serra Dourada. Tese de Livre-docência. Universidade Federal de Goiás, Goiânia. 91p.

Rodrigues, A.S. 2007. As tribos Dalechampieae Müll. Arg. e Manihoteae Melchior (Euphorbiaceae) no Distrito Federal, Brasil. Dissertação de Mestrado. Universidade de Brasília, Brasília. 104p.

Rogers, D.J. \& Appan, S.G. 1973. Manihot and Manihotoides (Euphorbiaceae). A computerassisted study. Flora Neotropica, Monograph no.13. Hafner Press, New York. 272p.

Santos-Filho, F.S. 2000. A família Euphorbiaceae Juss. no Parque Estadual Zoobotânico na cidade de Teresina, Piauí-Brasil. Dissertação de Mestrado. Universidade Federal de Pernambuco, Recife. $104 \mathrm{p}$.

Sátiro, L.N. \& Roque, N. 2008. A família Euphorbiaceae nas caatingas arenosas do médio rio São Francisco, BA, Brasil. Acta Botanica Brasílica 22: 99-118.

Secco, R.S.; Cordeiro, I.; Senna-Vale, L.; Sales, M.F.; Lima, L.R.; Medeiros, D.; Sá Haiad, B.; Oliveira, A.S.; Caruzo, M.B.R.; Carneiro-Torres, D. \& Bigio, N.C. 2012. An overview of recent 
taxonomic studies on Euphorbiaceae s.l. in Brazil. Rodriguésia 63: 227-2012.

Smith, L.B.; Downs, R.J. \& Klein, R.M. 1988. Euphorbiaceae - Croton L. Flora Ilustrada Catarinense. Fasc. EUFO. Pp. 62-137.

Thiers, B. 2012. Index herbariorum: a global directory of public herbaria and associated staff. New York Botanical Garden's Virtual Herbarium. Disponível em $<$ http://sciweb.nybg. org/science $2 /$ IndexHerbariorum.asp $>$. Acesso em 21 Dez 2012.

Webster, G.L. 1994. Classification of the Euphorbiaceae. Annals of the Missouri Botanical Garden 81: 3-32. 